\title{
Ecopreneur Selection Using Fuzzy Similarity TOPSIS Variants
}

\author{
Shirin Noei', Arman Sargolzaei², Kang Yen ${ }^{3}$, Saman Sargolzaei, ${ }^{4,5}$ Nansong Wu ${ }^{6}$ \\ ${ }^{1}$ Department of Civil and Environmental Engineering, University of Florida, Gainesville, FL, USA \\ ${ }^{2}$ Department of Electrical Engineering, Florida Polytechnic University, Lakeland, FL, USA \\ ${ }^{3}$ Department of Electrical and Computer Engineering, Florida International University, Miami, FL, USA \\ ${ }^{4}$ Rancs Group LLC, Wilmington, DE, USA \\ ${ }^{5}$ Department of Neurosurgery, University of California at Los Angeles, Los Angeles, CA, USA \\ ${ }^{6}$ Department of Electrical Engineering, Arkansas Tech University, Russellville, AR, USA \\ Email: noei.shirin@gmail.com
}

How to cite this paper: Noei, S., Sargolzaei, A., Yen, K., Sargolzaei, S. and $\mathrm{Wu}$, N.S. (2017) Ecopreneur Selection Using Fuzzy Similarity TOPSIS Variants. American Journal of Industrial and Business Management, 7, 864-880.

https://doi.org/10.4236/ajibm.2017.77061

Received: May 17, 2017

Accepted: July 4, 2017

Published: July 7, 2017

Copyright $\odot 2017$ by authors and Scientific Research Publishing Inc. This work is licensed under the Creative Commons Attribution International License (CC BY 4.0).

http://creativecommons.org/licenses/by/4.0/

\begin{abstract}
A supply chain network coordinates flow of components from different suppliers to enhance a product that meets customers' value expectations. Traditionally, companies consider price, quality, and lead time for selecting appropriate suppliers. Increasing environmental concerns, government regulations, and long-term profitability have forced companies to reduce pollution. In addition, in a complex business environment, supply managers should have flexibility skills to act entrepreneurially. Being ecopreneur is a paradigm modification from being a green supplier and entrepreneur toward global economy and sustainability. Although ecopreneur selection is a strategic key to project success, construction industry lacks a systematic approach for decision-making processes. When historical data are not available or adequate, subjective judgment of experts is the only source of information for decision. Fuzzy logic helps decision makers to translate qualitative terms into quantitative information, whereas TOPSIS method ranks alternatives according to their relative distance to the ideal solution. This paper aims to rank ecopreneurs according to the criteria for green entrepreneur selection. In this case, construction-related experts are interviewed to first rate the importance of each criterion as their point of view, and then rate performance of each candidate in accordance to the most important criteria for ecopreneur selection. The final response is expressed based on the average of new variants of fuzzy TOPSIS each using a different fuzzy similarity measure. A numerical example is also presented to illustrate the process in detail.
\end{abstract}

\section{Keywords}

Supply Chain Management, Ecopreneur Selection, New Variants of Fuzzy TOPSIS, Similarity Measure 


\section{Introduction}

Properties of raw materials heavily impact features of final product. Supply Chain Management (SCM) can be considered as the process of designing, planning, executing, and controlling a network. This process collimates flow of raw materials from vendors to manufactures, and utilizes companies to manage their suppliers [1]. It also encompasses transportation and storage of commodities from place of origin to place of consumption. Products and services needed by ultimate consumers heavily influence connected networks [2]. The overall objective of SCM is to generate net value, create a competitive advantage, organize supplies with demands, and monitor project performance.

Suppliers are one of the most important elements of an organization. Companies outsource provision of raw materials, products, and services to a supplier who can provide satisfactory, economic, and on-time products [3]. In other words, purchasing and procurement of an enterprise depend on the merchandise of its suppliers. Considering the fact that dangerous substances may seriously harm the environment, selecting an appropriate vendor who can offer right quality products at a proper time in a promising manner becomes extremely important. Traditionally, companies consider cost, quality, delivery time, and services as criteria to evaluate performance of suppliers. Today, the process of purchasing is more sophisticated.

According to Bhutta and Huq [4], selecting a supplier is a consequential decision-making challenge with multi attributes. Environment-friendly and recyclable substances, ecological management systems, and life-cycle analysis are critical issues in designing a network. Increasing awareness of environmental protection, government regulations, and long-term profitability transform sustainability to a main consideration of developing enterprises [5]. The main role of suppliers in demonstrating ecological function and environmental sustainability makes supplier selection process a serious issue in purchasing management.

Speedy changes in business circumstances push purchasing and supply managers to acquire a new set of Purchase and Supply Management (P/SM) flexibility skills to effectively resolve business complications [6]. Innovation is the most important attribute, which distinguishes entrepreneurs from owners of small businesses. Despite the fact that risks are inevitable, they can be taken, threaten, transferred, or terminated by entrepreneurs [7]. In addition, flexible supply chains are more capable of adapting to uncertainties about demands.

Ecopreneur is an entrepreneur who is not only concerned about making profit, but also about environmental issues. Sustainopreneurship, environmental entrepreneurship, and eco-capitalism are common terms for ecopreneurship. Global population growth, increasing life expectancy, climate change, resource scarcity, lack of equity in the world, and human rights are major drivers for ecopreneurialism.

SCM organizes a network of suppliers, manufacturers, distributers, and consumers with respect to cost, quality, lead time, operational delivery, service level, and social responsibility. Proceeding with the introduction of supply chain, a 
new paradigm has attracted attentions. Sustainability issues are major drivers for transformation of supply chain to green supply chain. Since they were not comprehensive terms, entrepreneurial supply chain come into consideration. Ecopreneur is assigned to those entrepreneurs who have innovation and flexibility skills to maintain economic, environmental, and social concerns, while committed to satisfy customers' expectations. The main objectives of the current study are 1) to determine a set of criteria for ecopreneur selection and 2) to rank nominates according to the subjective judgment of experts. The fuzzy set with trapezoid membership function is utilized for ranking purposes. A fuzzy Technique for Order of Preferences by Similarity to Ideal Solution (TOPSIS) method is introduced for solving Multi Criteria Decision-Making (MCDM) problems. Then, new fuzzy TOPSIS variants using similarity measures are introduced. Finally, the candidates are ranked from the best to the worst according to the average of all the aforementioned algorithms.

\section{Literature Review}

Components of SCM have qualitative and quantitative characteristics. Dickson conducted a survey which represented 23 criteria related to supplier's selection and evaluation of their performance [8]. Weber highlighted quality, delivery, and performance history out of the pool of indices [9]. Hu realized that quality, cost, production capacity, and delivery are the main concerns [10]. Bayraktar and Celbi arranged 37 criteria into: quality, cost, delivery, and service. They developed Data Envelopment Analysis (DEA) and Artificial Neural Networks (ANN) to evaluate suppliers based on the incorrect or inappropriate information [11].

Noci utilized Analytical Hierarchy Process (AHP) to develop an effective decision-making tool for selecting a green supplier [12]. Sarkis divided business practices concerning environmental consciousness into green design, environmental management, life-cycle analysis, Green Supply Chain (GSC) certificates, and official documents such as ISO 14,000 [13]. Furthermore, Handfield used Delphi method to gather professional's viewpoints from different well-known companies. Then he applied AHP to formulate supplier's performance [14]. Noci proposed attributes for evaluating environmental performance [15]. Humphreys presented more mature criteria with the emphasis on environmental cost [16]. Later, Sarkis developed a six-dimensional framework for GSC decision-making using Analytic Network Process (ANP) [17]. Hsu and Hu introduced new attributes for selecting supplier with consideration of hazardous substance management [10]. Tseng applied hybrid fuzzy grey relational analysis to evaluate suppliers in regard to environmental management abilities with lack of information and uncertainty [18]. Bai and Sarkis integrated sustainability into the selection of suppliers by utilizing the grey system and rough set methods [17]. Awasthi evaluated supplier's environmental performance by applying fuzzy TOPSIS approach [19].

Yeh and Chuang proposed a multi-objective genetic algorithm for choosing a 
proper partner in green supply chain problems [20]. Buyukozkan and Cifci developed a novel fuzzy multi-criteria decision framework for sustainable supplier selection with incomplete information [21]. "Zhu et al. evaluated green supplier development programs through a telecommunications system provider [22]". Buyukozkan and Cifi applied a new approach based on Fuzzy Analytic Neural Process (FANP), which could consider multi-person decision making schema in case of inadequate data [21]. Shaw et al. presented an integrated approach using fuzzy AHP and fuzzy multi-objective linear programming for selecting an appropriate supplier in a supply chain addressing the carbon issue [23]. Govindan et al. assessed supplier's sustainability performance by utilizing fuzzy multi-criteria approach. He considered eco design, resource consumption, environmental management system, and pollution production as criteria for green supplier selection [24]. Timmons introduced commitment, determination, leadership, tolerance of risk, internal motivation, and creativity as the most important characteristics of an entrepreneur [25]. Entrepreneurs have direct influence on the company's success or failure. They are able to identify potential opportunities and grab them. According to Goodman, the reason behind their success is their ability to envisage scenarios [26]. Successful entrepreneurs manage risky events and their monetary consequences. Entrepreneurial firms are innovative, proactive, and have tolerance of risk [27]. Hence, no company chooses to be conservative or selects the "wait and see" attitude. Entrepreneurship is considered as the process of "creative destruction", that means demolishing existing methods and replacing new ones. This point offers a reform in terms of process or product usefulness [28]. As a result of this reform, an overall economic activity and buyer interest can be triggered increasingly. Table 1 summarizes the main criteria for supplier selection.

\section{Fuzzy Set}

As construction projects become increasingly dynamic, decision-making processes become more complex accordingly [32]. Traditionally, managers make decisions based on subjective judgments. This procedure is not rational enough to be defendable [33]. In addition, it is not practical for large projects that need a systematic approach. Prior to selecting ecopreneurs, owners should evaluate their candidates in accordance with their recorded history [34]. The chance of making right decisions decreases as projects become more sophisticated. On the other hand, most of the risk analysis methods are based on numerical data and need quantitative calculations. If data are insufficient, stochastic methods are used to simulate data. When data are not available, subjective judgments are the only way to quantify risky elements. Fuzzy set is a mathematical tool to identify, evaluate, and monitor risky endeavors. This theory is used for those projects that data regarding the probability of the occurrence of risk events or their monetary consequences is inadequate or unavailable. This qualitative method can provide a competitive advantage for those enterprises that do not have an accurate source of information. However human judgments are ambiguous, we need exact numerical values to simulate real life problems. 
Table 1. Literature review.

\begin{tabular}{|c|c|}
\hline Researcher & Article abstract \\
\hline Noci [12] & $\begin{array}{l}\text { Economic performance, } \\
\text { Physical performance (energy consumption) }\end{array}$ \\
\hline Sarkis [13] & $\begin{array}{l}\text { Life-cycle analysis, Design for the environment, } \\
\text { Total quality environmental management, } \\
\text { GSC \& ISO 14,000 certificates and requirements }\end{array}$ \\
\hline Azzone and Noci [15] & $\begin{array}{l}\text { Green image, External environmental effectiveness, } \\
\text { Environmental flexibility, Green capability, } \\
\text { Current environmental efficiency, Net life-cycle cost }\end{array}$ \\
\hline Sarkis, Zhu et al. [29] & $\begin{array}{l}\text { Environmental certification, Eco design, Clean technologies, } \\
\text { Utilizing environmental-friendly materials, Parking return and reuse, } \\
\text { Waste management, Reducing environmental emissions }\end{array}$ \\
\hline Handfield et al. [14] & $\begin{array}{c}\text { ISO } 14,000 \text { certificate, Recycle content, Participating in } \\
\text { Environmental Protection Agency (EPA) non-mandatory programs, } \\
\text { Public disclosure of environmental record }\end{array}$ \\
\hline Humphreys et al. [16] & $\begin{array}{l}\text { Green design, Green image, Manage capability, } \\
\text { Environmental management and competencies }\end{array}$ \\
\hline Zhu et al. [22] & $\begin{array}{l}\text { Performance in environmental issues, economic } \\
\text { performance issues, Eco-design, ISO } 14000 \text { certified, } \\
\text { GSCM Commitment by high-ranking managers }\end{array}$ \\
\hline Hsu and $\mathrm{Hu}[10]$ & $\begin{array}{l}\text { Ability of green designing, Green purchasing, } \\
\text { Green materials coding, Hazardous substance management, } \\
\text { Provision inventory of hazardous materials, } \\
\text { Environmental management, Competency of legal compliance }\end{array}$ \\
\hline Lee et al. [30] & $\begin{array}{l}\text { Green image, Environmental management, } \\
\text { Green capability, Green product, Green packaging, } \\
\text { Pollution control, Total product life cycle cost }\end{array}$ \\
\hline Kuo et al. [31] & $\begin{array}{l}\text { Eco design, Ozone depleting substances, } \\
\text { Restriction and control over hazardous substances, } \\
\text { Environmental management certification }\end{array}$ \\
\hline Awasthi et al. [19] & $\begin{array}{l}\text { Utilizing environmental-friendly technology, Applying } \\
\text { environmental-friendly materials, Partnership with green } \\
\text { organizations, Green market share, Applying environmental policies, } \\
\text { Staff training, Design for the environment, Lean process planning, } \\
\text { Environmental certification, Pollution controls, } \\
\text { Pollution production, Resource consumption }\end{array}$ \\
\hline Bai and Sarkis [17] & $\begin{array}{l}\text { Environmental management systems, Resource consumption, } \\
\text { Pollution production, Resource consumption }\end{array}$ \\
\hline Yeh and Chuang [20] & $\begin{array}{l}\text { Green design, Application of GSCM, Green image, } \\
\text { Recycling of products, Environmental performance } \\
\text { evaluation, Pollution treatment cost }\end{array}$ \\
\hline Tseng and Chiu [18] & $\begin{array}{l}\text { Environmental certificates (e.g. ISO 14,000), Design for the environment, } \\
\text { Total quality environment management, Life-cycle analysis, Green } \\
\text { production plan, Green purchasing, Reduction in hazardous substances, } \\
\text { Environmental management system, Environmentally preferable } \\
\text { bidding, Innovativeness of R \& D green products }\end{array}$ \\
\hline Govindan et al. [24] & $\begin{array}{l}\text { Eco design, Resource consumption, } \\
\text { Environmental management system, Pollution production }\end{array}$ \\
\hline
\end{tabular}


In 1965, Zadeh introduced fuzzy set can be applied to model vagueness of human cognition [35]. Fuzzy logic has many applications in vast range of sciences [36] [37] [38]. In the crisp set each element either belongs to the set or not, but in the fuzzy set each element can partially belong to the set with a unique degree of membership expressed in terms of values ranging between zero and one. Let us consider $\mu$ as a member of a fuzzy subset $F$. The membership function $h_{f}(\mu)$ can have a real value between0and1, which implies the range of membership degree (Figure 1).

$$
h_{f}(\mu)=\left\{\begin{array}{lc}
0 & \mu<a \\
\frac{\mu-a}{b-a} & a \leq \mu<b \\
1 & b \leq \mu<c \\
\frac{d-\mu}{d-c} & c \leq \mu<d \\
0 & \mu \geq d
\end{array}\right.
$$

\section{Extended Fuzzy TOPSIS Method}

Because of incomplete and imprecise information, managers cannot make right decisions about future performance of candidates [18] [39]. In this case, decision-making tools can help managers to determine the best alternative. Technique for Order of Preference by Similarity to Ideal Solution (TOPSIS) is a classical method for solving Multi Criteria Decision Making (MCDM) problems. This method is based on the concept that the highest-rank alternative has the shortest distance from the Positive Ideal Solution (PIS), and is furthest away from the Negative Ideal Solution (NIS). It simplifies the trade-off between multi criteria and performance attributes, and avoids pair-wise comparisons [40]. This method can be used to rank alternatives based on their relative closeness to the ideal solution, or extended to the fuzzy environment where ratings and weights are triangular, trapezoid, and interval-valued fuzzy numbers [41]. Similarity measures are used to determine the similarity between the alternative and PIS, NIS, Fuzzy Positive Ideal Solution (FPIS), and Fuzzy Negative Ideal Solution (FNIS). The first similarity measure is defined for Fuzzy Numbers (FNs) and the

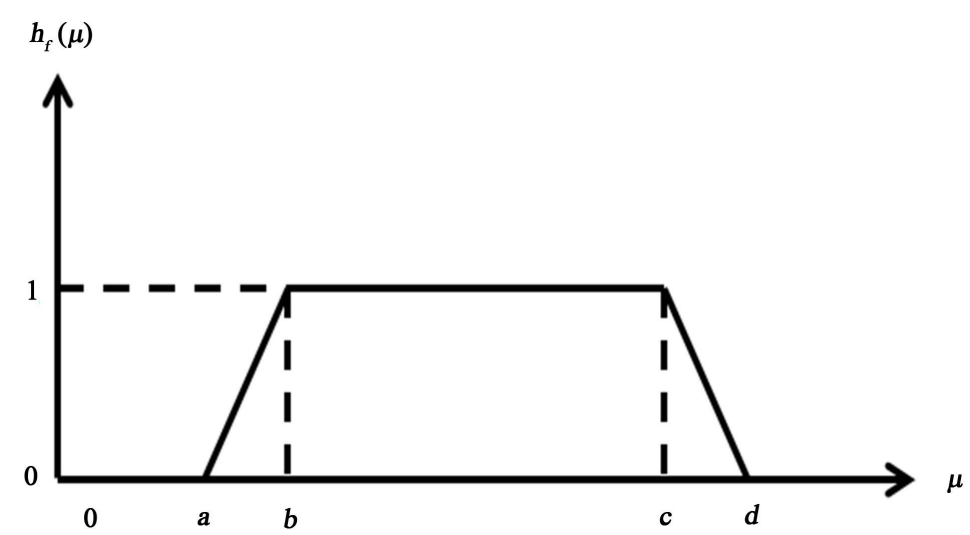

Figure 1. Trapezoid membership function. 
last three for Generalized Fuzzy Numbers (GFNs). There are four types of similarity measures each producing different set of results. To select better result, the idea is to statistically express the final result based on the average of all possible answers.

Let $A$ and $B$ be trapezoidal FNs

$$
A=\left(a_{1}, a_{2}, a_{3}, a_{4}, w_{a}\right) \text { and } B=\left(b_{1}, b_{2}, b_{3}, b_{4}, w_{b}\right)
$$

where $a_{1}, a_{2}, a_{3}, a_{4}, b_{1}, b_{2}, b_{3}, b_{4}$ are real values and $w_{a}, w_{b} \in(0,1]$.

1) The first similarity measure [2] between trapezoidal FNs $A$ and $B$ can be defined as [42]:

$$
S_{1}(A, B)=\frac{1}{d(A, B)}
$$

where $d(A, B)=\left|P_{1}(A)-P_{1}(B)\right|$ and $P_{1}(A)$ and $P_{1}(B)$ are the mean graded integration representation of $A$ and $B$ calculated as follows:

$$
\begin{gathered}
P_{1}(A)=\frac{a_{1}+2 a_{2}+2 a_{3}+a_{4}}{6} \\
P_{1}(B)=\frac{b_{1}+2 b_{2}+2 b_{3}+b_{4}}{6}
\end{gathered}
$$

2) The second, third, and fourth similarity measures are calculated based on $A=\left(a_{1}, a_{2}, a_{3}, a_{4}, w_{a}\right)$ and $B=\left(b_{1}, b_{2}, b_{3}, b_{4}, w_{b}\right)$ which are two trapezoidal GFNs. The second similarity measure $[3]$ is calculated as:

$$
S_{2}(A, B)=\left(1-\frac{\sum_{i=1}^{4}\left|a_{i}-b_{i}\right|}{4}\right) \times\left(1-\left|X_{a}-X_{b}\right|\right)^{\left[\frac{S_{a}-S_{b}}{2}\right]} \times \frac{\min \left(Y_{a}, Y_{b}\right)}{\max \left(Y_{a}, Y_{b}\right)}
$$

$\left\lceil\frac{S_{a}-S_{b}}{2}\right\rceil=0$ when $S_{a}=S_{b}$, and $\left\lceil\frac{S_{a}-S_{b}}{2}\right\rceil=1$ when $0<\frac{S_{a}-S_{b}}{2} \leq 1 .\left(X_{a}\right.$, $\left.Y_{a}\right)$ and $\left(X_{b}, Y_{b}\right)$ are Centre of Gravity (COG) points for trapezoidal GFNs $A$ and $B$ computed as:

$$
\begin{gathered}
X_{a}=\frac{Y_{a}\left(a_{3}+a_{2}\right)+\left(a_{4}+a_{1}\right)\left(w_{a}-Y_{a}\right)}{2 w_{a}} \\
Y_{a}= \begin{cases}w_{a}\left(\frac{a_{3}-a_{2}}{a_{4}-a_{1}}\right) & a_{1} \neq a_{4} \text { and } 0<w_{a} \leq 1 \\
\frac{w_{a}}{2} & a_{1}=a_{4} \text { and } 0<w_{a} \leq 1\end{cases}
\end{gathered}
$$

Similarly, $X_{b}$ and $Y_{b}$ can be defined through parameters of B.

3) The third similarity measure [1] is defined as:

$$
S_{3}(A, B)=\left(1-\frac{\sum_{i=1}^{4}\left|a_{i}-b_{i}\right|}{4}\right) \times\left(\frac{\min \left(P_{2}(A), P_{2}(B)\right)+\min \left(w_{a}, w_{b}\right)}{\max \left(P_{2}(A), P_{2}(B)\right)+\max \left(w_{a}, w_{b}\right)}\right)
$$

where $P_{2}(A)$ and $P_{2}(B)$ are parameters of trapezoidal GFNs $A$ and $B$ calculated as: 


$$
\begin{array}{r}
P_{2}(A)=\sqrt{\left(a_{1}-a_{2}\right)^{2}+w_{a}^{2}}+\sqrt{\left(a_{3}-a_{4}\right)^{2}+w_{a}^{2}}+\left(a_{3}-a_{2}\right)+\left(a_{4}-a_{1}\right) \\
P_{2}(B)=\sqrt{\left(b_{1}-b_{2}\right)^{2}+w_{b}^{2}}+\sqrt{\left(b_{3}-b_{4}\right)^{2}+w_{b}^{2}}+\left(b_{3}-b_{2}\right)+\left(b_{4}-b_{1}\right)
\end{array}
$$

Hejazi proposed the fourth similarity measure considering geometric distance, perimeter, and area of the two trapezoid GFNs defined as:

$$
\begin{aligned}
S_{4}(A, B)= & \left(1-\frac{\sum_{i=1}^{4}\left|a_{i}-b_{i}\right|}{4}\right) \times\left(\frac{\min \left(P_{2}(A), P_{2}(B)\right)}{\max \left(P_{2}(A), P_{2}(B)\right)}\right) \\
& \times\left(\frac{\min (\text { Area }(A), \text { Area }(B))+\min \left(w_{a}, w_{b}\right)}{\max (\text { Area }(A), \text { Area }(B))+\max \left(w_{a}, w_{b}\right)}\right)
\end{aligned}
$$

where areas of trapezoidal GFNs are defined as:

$$
\begin{aligned}
& \operatorname{Area}(A)=\frac{1}{2} w_{a}\left(a_{3}-a_{2}+a_{4}-a_{1}\right) \\
& \operatorname{Area}(B)=\frac{1}{2} w_{b}\left(b_{3}-b_{2}+b_{4}-b_{1}\right)
\end{aligned}
$$

Assume a set of ecopreneurs $\left\{E_{i} \mid i=1,2, \cdots, m\right\}$ need to be evaluated by a committee of decision makers $D=\left\{D_{l} \mid l=1,2, \cdots, k\right\}$ considering a set of criteria $C=\left\{C_{j} \mid j=1,2, \cdots, n\right\}$. Decision matrix representation of performance ratings of each ecopreneur $E_{p}$ with respect to each criterion $C_{p}$ is presented as follows:

$$
X=\left[\begin{array}{ccc}
x_{11} & \cdots & x_{1 n} \\
\vdots & \ddots & \vdots \\
x_{m 1} & \cdots & x_{m n}
\end{array}\right]
$$

where $m$ rows represent possible number of candidates, $n$ columns represent relevant number of criteria, and $x_{i j}$ represents the performance rating of the $i$ th candidate with respect to the $t$ th criterion. These ratings are trapezoidal FNs with height equaling to one for all cases. The set of weights for criteria is assumed to be $W=\left[w_{1}, w_{2}, \cdots, w_{n}\right]$. The aforementioned fuzzy decision matrix is formed for each decision maker $D_{r}$. To aggregate the fuzzy decision matrices of each decision maker to one single decision matrix, an aggregated trapezoidal FN, $R=(a, b, c, d)$ is calculated using $a=\min \left\{a_{l}\right\}, \quad b=\frac{1}{k} \sum_{l=1}^{k} b_{l}, \quad c=\frac{1}{k} \sum_{l=1}^{k} c_{l}$, and $d=\max \left\{d_{l}\right\}$.

Therefore, the normalized fuzzy decision matrix can be defined as:

$$
R=\left(r_{i j}\right)_{m n}
$$

The criteria set can also be divided into $B n$ and $C$ which are benefit and cost criteria, respectively.

$$
r_{i j}=\left(\frac{a_{i j}}{d_{j}^{\oplus}}, \frac{b_{i j}}{d_{j}^{\oplus}}, \frac{c_{i j}}{d_{j}^{\oplus}}, \frac{d_{i j}}{d_{j}^{\oplus}}\right), j \in B n
$$




$$
r_{i j}=\left(\frac{a_{j}^{*}}{d_{i j}}, \frac{a_{j}^{*}}{c_{i j}}, \frac{a_{j}^{*}}{b_{i j}}, \frac{a_{j}^{*}}{a_{i j}}\right), j \in C
$$

where $d_{j}^{\oplus}=\max _{i}\left(d_{i j}\right)$ and $a_{j}^{*}=\min _{i}\left(a_{i j}\right)$.

The weighted normalized decision matrix $V$ is calculated by multiplying the normalized matrix $R$ with weight of the th criteria:

$$
V=\left(v_{i j}\right)_{m n}
$$

Then, FPIS and FNIS are calculated as $A^{\oplus}$ and $A^{*}$ respectively:

$$
\begin{aligned}
A^{\oplus} & =\left[v_{1}^{+}, v_{2}^{+}, \cdots, v_{n}^{+}\right] \\
A^{*} & =\left[v_{1}^{-}, v_{2}^{-}, \cdots, v_{n}^{-}\right]
\end{aligned}
$$

Since there are four similarity measures, the maximum $v_{j}^{+}$and the minimum $v_{j}^{-}$weighted normalized values are defined as:

$$
\begin{gathered}
v_{j}^{+}=\max _{i} v_{i j 4} \\
v_{j}^{-}=\min _{i} v_{i j 1}
\end{gathered}
$$

Fuzzy similarities to FPIS and FNIS are calculated as:

$$
\begin{aligned}
S_{i}^{\oplus} & =\sum_{j=1}^{n} S_{v}\left(v_{i j}, v_{j}^{+}\right), \quad i=1,2, \cdots, m \\
S_{i}^{*} & =\sum_{j=1}^{n} S_{v}\left(v_{i j}, v_{j}^{-}\right), \quad i=1,2, \cdots, m
\end{aligned}
$$

Closeness Coefficient $C C_{i}$ for each alternative is calculated as:

$$
C C S_{i}=\frac{S_{i}^{\oplus}}{S_{i}^{*}+S_{i}^{\oplus}}, \quad i=1,2, \cdots, m
$$

\section{Results}

According to the detailed literature review, the most important criteria for evaluation of socio-environmental performance of entrepreneurs have been selected. Cost, quality, operational delivery, service level, environmental management, corporate social responsibility, technical knowledge, reputation, creativity and flexibility are described in Table 2, where $\mathrm{C}_{1}$ is cost criteria and the rest are benefit criteria. For cost criteria as value increases, desirability decrease [43]. The more benefit values, the more preferable the candidate. Environmental and construction experts have been asked to score those criteria according to their importance for an ecopreneur selection (Table 3). Linguistic preferences are determined in seven states from Very Low (VL), Low (L), Medium Low (ML), Medium $(\mathrm{M})$, Medium High $(\mathrm{MH})$, High $(\mathrm{H})$ and Very High $(\mathrm{VH})$ in Figure 2. Experts used linguistic terms to rate performance of each alternative for a given criteria ranging from Very Poor (VP), Poor (P), Medium Poor (MP), Fair (F), Medium Good (MG), Good (G), Very Good (VG) in Figure 3. $A_{1}, A_{2}, A_{3}$ are nominates evaluated by decision-makers $\mathrm{D}_{1}, \mathrm{D}_{2}, \mathrm{D}_{3}$. Tables 4-7 show simulation results step by step. The normalized fuzzy decision matrix and weighted norma- 


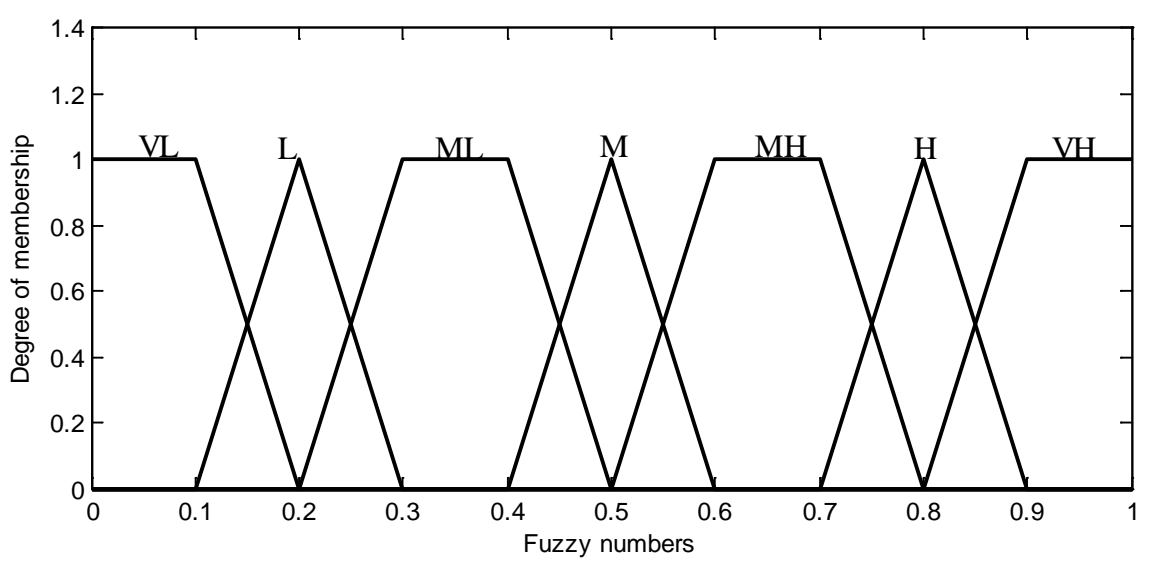

Figure 2. Linguistic variable for relative importance weight of criteria [10].

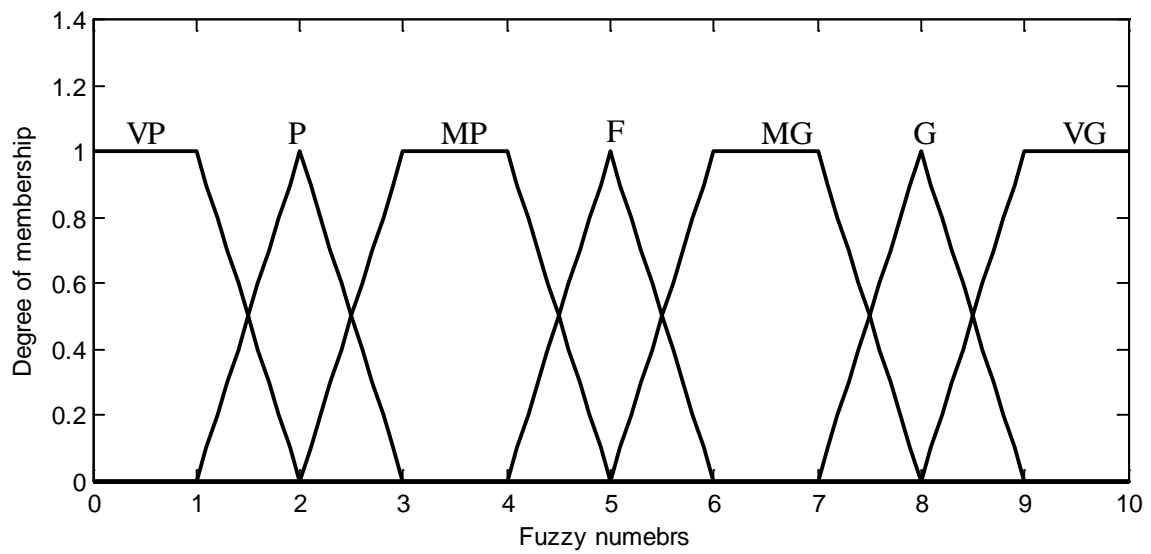

Figure 3. Linguistic variable for rating [10].

Table 2. Criteria for ecopreneur selection.

\begin{tabular}{|c|c|c|}
\hline & Criteria & Definition \\
\hline$C_{1}$ & Cost & Coordination with sector cost, Transportation pollutant \\
\hline$C_{2}$ & Quality & $\begin{array}{c}\text { Process improvement, Quality management, } \\
\text { Quality assurance, Reject rate }\end{array}$ \\
\hline$C_{3}$ & $\begin{array}{l}\text { Operational } \\
\text { delivery }\end{array}$ & Lead time, Order fulfil rate, Order frequency \\
\hline$C_{4}$ & Service level & Responsiveness, Willingness, Stock management \\
\hline$C_{5}$ & $\begin{array}{l}\text { Environmental } \\
\text { friendly }\end{array}$ & $\begin{array}{l}\text { Eco design, Restriction of hazardous materials, ISO 14,000, } \\
\text { Environmental policies, Staff environmental training, } \\
\text { Use of environmental-friendly materials, } \\
\text { Environmental management system, Carbon emission }\end{array}$ \\
\hline$C_{6}$ & Social responsibility & $\begin{array}{l}\text { Respect for the policy, The right of stakeholders } \\
\text { and employees, Information disclosure }\end{array}$ \\
\hline$C_{7}$ & Technical knowledge & $\begin{array}{c}\text { Management system and related competencies, } \\
\text { staff technical training }\end{array}$ \\
\hline$C_{8}$ & Reputation & $\begin{array}{l}\text { Green image, positive and effective partnership with } \\
\text { other green suppliers, customer reviews and satisfaction }\end{array}$ \\
\hline$C_{9}$ & Creativity & $\begin{array}{l}\text { creative destruction, new products, degree of innovativeness of } \\
\text { R \& D green products, applying risk management solutions }\end{array}$ \\
\hline$C_{10}$ & Flexibility & Adapt to uncertainties, adopt to customers' demand \\
\hline
\end{tabular}


Table 3. Linguistic assessment of decision makers.

\begin{tabular}{cccc}
\hline Criteria & $\mathrm{DM}_{1}$ & $\mathrm{DM}_{2}$ & $\mathrm{DM}_{3}$ \\
\hline$C_{1}$ & $\mathrm{H}$ & $\mathrm{VH}$ & $\mathrm{H}$ \\
$C_{2}$ & $\mathrm{H}$ & $\mathrm{M}$ & $\mathrm{MH}$ \\
$C_{3}$ & $\mathrm{VH}$ & $\mathrm{VH}$ & $\mathrm{H}$ \\
$C_{4}$ & $\mathrm{M}$ & $\mathrm{MH}$ & $\mathrm{M}$ \\
$C_{5}$ & $\mathrm{H}$ & $\mathrm{H}$ & $\mathrm{MH}$ \\
$C_{6}$ & $\mathrm{MH}$ & $\mathrm{M}$ & $\mathrm{MH}$ \\
$C_{7}$ & $\mathrm{M}$ & $\mathrm{MH}$ & $\mathrm{MH}$ \\
$C_{8}$ & $\mathrm{H}$ & $\mathrm{H}$ & $\mathrm{MH}$ \\
$C_{9}$ & $\mathrm{M}$ & $\mathrm{ML}$ & $\mathrm{ML}$ \\
$C_{10}$ & $\mathrm{M}$ & $\mathrm{H}$ & $\mathrm{H}$ \\
\hline
\end{tabular}

Table 4. Fuzzy weights of criteria.

\begin{tabular}{ccccc}
\hline Criteria & $\mathrm{DM}_{1}$ & $\mathrm{DM}_{2}$ & $\mathrm{DM}_{3}$ & Aggregate Fuzzy Weights \\
\hline$C_{1}$ & $(0.7,0.8,0.8,0.9,1)$ & $(0.8,0.9,1.0,1.0,1)$ & $(0.7,0.8,0.8,0.9,1)$ & $(0.70,0.83,0.87,1.00,1)$ \\
$C_{2}$ & $(0.7,0.8,0.8,0.9,1)$ & $(0.4,0.5,0.5,0.6,1)$ & $(0.5,0.6,0.7,0.8,1)$ & $(0.40,0.63,0.67,0.90,1)$ \\
$C_{3}$ & $(0.8,0.9,1.0,1.0,1)$ & $(0.8,0.9,1.0,1.0,1)$ & $(0.7,0.8,0.8,0.9,1)$ & $(0.70,0.87,0.93,1.00,1)$ \\
$C_{4}$ & $(0.4,0.5,0.5,0.6,1)$ & $(0.5,0.6,0.7,0.8,1)$ & $(0.4,0.5,0.5,0.6,1)$ & $(0.40,0.53,0.57,0.80,1)$ \\
$C_{5}$ & $(0.7,0.8,0.8,0.9,1)$ & $(0.7,0.8,0.8,0.9,1)$ & $(0.5,0.6,0.7,0.8,1)$ & $(0.50,0.73,0.77,0.90,1)$ \\
$C_{6}$ & $(0.5,0.6,0.7,0.8,1)$ & $(0.4,0.5,0.5,0.6,1)$ & $(0.5,0.6,0.7,0.8,1)$ & $(0.40,0.57,0.63,0.80,1)$ \\
$C_{7}$ & $(0.4,0.5,0.5,0.6,1)$ & $(0.5,0.6,0.7,0.8,1)$ & $(0.5,0.6,0.7,0.8,1)$ & $(0.40,0.57,0.63,0.80,1)$ \\
$C_{8}$ & $(0.7,0.8,0.8,0.9,1)$ & $(0.7,0.8,0.8,0.9,1)$ & $(0.5,0.6,0.7,0.8,1)$ & $(0.50,0.73,0.77,0.90,1)$ \\
$C_{9}$ & $(0.4,0.5,0.5,0.6,1)$ & $(0.2,0.3,0.4,0.5,1)$ & $(0.2,0.3,0.4,0.5,1)$ & $(0.20,0.37,0.43,0.60,1)$ \\
$C_{10}$ & $(0.4,0.5,0.5,0.6,1)$ & $(0.7,0.8,0.8,0.9,1)$ & $(0.7,0.8,0.8,0.9,1)$ & $(0.40,0.70,0.70,0.90,1)$ \\
\hline
\end{tabular}

Table 5. Rating of $A_{1}$.

\begin{tabular}{ccccc}
\hline Criteria & $\mathrm{DM}_{1}$ & $\mathrm{DM}_{2}$ & $\mathrm{DM}_{3}$ & Aggregate Fuzzy Weights \\
\hline$C_{1}$ & $\mathrm{~F}$ & $\mathrm{MG}$ & $\mathrm{MP}$ & $(2.00,4.67,5.33,8.00,1.00)$ \\
$C_{2}$ & $\mathrm{MG}$ & $\mathrm{MP}$ & $\mathrm{F}$ & $(2.00,4.67,5.33,8.00,1.00)$ \\
$C_{3}$ & $\mathrm{MG}$ & $\mathrm{MG}$ & $\mathrm{MP}$ & $(2.00,5.00,6.00,8.00,1.00)$ \\
$C_{4}$ & $\mathrm{~F}$ & $\mathrm{P}$ & $\mathrm{MP}$ & $(1.00,3.33,3.67,6.00,1)$ \\
$C_{5}$ & $\mathrm{MG}$ & $\mathrm{MG}$ & $\mathrm{F}$ & $(4.00,5.67,6.33,8.00,1)$ \\
$C_{6}$ & $\mathrm{P}$ & $\mathrm{VP}$ & $\mathrm{MP}$ & $(0.00,1.67,2.33,5.00,1)$ \\
$C_{7}$ & $\mathrm{MP}$ & $\mathrm{MP}$ & $\mathrm{F}$ & $(2.00,3.67,4.33,6.00,1)$ \\
$C_{8}$ & $\mathrm{MP}$ & $\mathrm{MG}$ & $\mathrm{MP}$ & $(2,00,4.00,5.00,8.00,1)$ \\
$C_{9}$ & $\mathrm{~F}$ & $\mathrm{MP}$ & $\mathrm{MP}$ & $(2.00,3.67,4.33,6.00,1)$ \\
$C_{10}$ & $\mathrm{P}$ & $\mathrm{MP}$ & $\mathrm{F}$ & $(1.00,3.33,3.67,6.00,1)$ \\
\hline
\end{tabular}


Table 6. Rating of $A_{2}$.

\begin{tabular}{ccccc}
\hline Criteria & $\mathrm{DM}_{1}$ & $\mathrm{DM}_{2}$ & $\mathrm{DM}_{3}$ & Aggregate Fuzzy Weights \\
\hline$C_{1}$ & $\mathrm{VG}$ & $\mathrm{G}$ & $\mathrm{MG}$ & $(5.00,7.67,8.33,10.00,1.00)$ \\
$C_{2}$ & $\mathrm{~F}$ & $\mathrm{G}$ & $\mathrm{F}$ & $(4.00,6.00,6.00,9.00,1.00)$ \\
$C_{3}$ & $\mathrm{MG}$ & $\mathrm{MG}$ & $\mathrm{F}$ & $(4.00,5.67,6.33,8.00,1.00)$ \\
$C_{4}$ & $\mathrm{MG}$ & $\mathrm{F}$ & $\mathrm{MP}$ & $(2.00,4.67,5.33,8.00,1.00)$ \\
$C_{5}$ & $\mathrm{G}$ & $\mathrm{MG}$ & $\mathrm{MP}$ & $(2.00,5.67,6.33,9.00,1.00)$ \\
$C_{6}$ & $\mathrm{MP}$ & $\mathrm{F}$ & $\mathrm{MG}$ & $(2.00,4.67,5.33,8.00,1.00)$ \\
$C_{7}$ & $\mathrm{VG}$ & $\mathrm{G}$ & $\mathrm{VG}$ & $(7.00,8.67,9.33,10.00,1.00)$ \\
$C_{8}$ & $\mathrm{MP}$ & $\mathrm{G}$ & $\mathrm{MG}$ & $(2.00,5.67,6.33,9.00,1.00)$ \\
$C_{9}$ & $\mathrm{G}$ & $\mathrm{G}$ & $\mathrm{VG}$ & $(7.00,8.33,8.67,10.00,1)$ \\
$C_{10}$ & $\mathrm{MG}$ & $\mathrm{F}$ & $\mathrm{MG}$ & $(4.00,2.67,3.33,5.00,1)$ \\
\hline
\end{tabular}

Table 7. Rating of $A_{3}$.

\begin{tabular}{ccccc}
\hline Criteria & $\mathrm{DM}_{1}$ & $\mathrm{DM}_{2}$ & $\mathrm{DM}_{3}$ & Aggregate Fuzzy Weights \\
\hline$C_{1}$ & $\mathrm{G}$ & $\mathrm{G}$ & $\mathrm{MG}$ & $(5.00,7.33,7.67,9.00,1)$ \\
$C_{2}$ & $\mathrm{MP}$ & $\mathrm{MP}$ & $\mathrm{MG}$ & $(2.00,4.00,5.00,8.00,1)$ \\
$C_{3}$ & $\mathrm{~F}$ & $\mathrm{G}$ & $\mathrm{F}$ & $(4.00,6.00,6.00,9.00,1)$ \\
$C_{4}$ & $\mathrm{MP}$ & $\mathrm{MP}$ & $\mathrm{F}$ & $(2.00,3.67,4.33,6.00,1)$ \\
$C_{5}$ & $\mathrm{MG}$ & $\mathrm{MG}$ & $\mathrm{MG}$ & $(5.00,6.00,7.00,8.00,1)$ \\
$C_{6}$ & $\mathrm{P}$ & $\mathrm{F}$ & $\mathrm{MP}$ & $(1.00,3.33,3.67,6.00,1)$ \\
$C_{7}$ & $\mathrm{G}$ & $\mathrm{G}$ & $\mathrm{MG}$ & $(5,00,7.33,7.67,9.00,1)$ \\
$C_{8}$ & $\mathrm{MG}$ & $\mathrm{F}$ & $\mathrm{G}$ & $(4.00,6.33,6.67,9.00,1)$ \\
$C_{9}$ & $\mathrm{G}$ & $\mathrm{MG}$ & $\mathrm{MG}$ & $(5.00,6.67,7.33,9.00,1)$ \\
$C_{10}$ & $\mathrm{MP}$ & $\mathrm{P}$ & $\mathrm{MP}$ & $(1.00,2.67,3.33,5.00,1)$ \\
\hline
\end{tabular}

lized fuzzy decision matrix for all three nominates are calculated based on Equations (15)-(18) and results can be found in Table 8 and Table 9. Tables 10-13 describe Score of Candidates using three different similarity measures. Using simulation, ecopreneurs are ranked according to their relative distance to FPIS and FNIS (Table 14).

\section{Conclusion}

Historical data are the most accurate source of information. Whenever companies lack adequate and precise data, subjective perception of experts is the only source of information. To select proper entrepreneurs, a set of criteria is formed to comply with objectives of the organization. Sustainability covers socio-economic, socio-environmental, and eco-efficiency issues. In a developing global market, companies need green entrepreneurs to improve their competitive advantage. Although process of selection is a key strategy to project success, construction industry lacks sufficiently quantitative researches on a comprehensive de- 
Table 8. Normalized fuzzy decision matrix.

\begin{tabular}{cccc}
\hline Criteria & \multicolumn{1}{c}{$A_{1}$} & $A_{2}$ & $A_{3}$ \\
\hline$C_{1}$ & $(0.25,0.38,0.43,1.00,1)$ & $(0.20,0.24,0.26,0.40,1)$ & $(0.22,0.26,0.27,0.4,1)$ \\
$C_{2}$ & $(0.22,0.52,0.59,0.89,1)$ & $(0.44,0.67,0.67,1.00,1)$ & $(0.22,0.44,0.56,0.89,1)$ \\
$C_{3}$ & $(0.22,0.56,0.67,0.89,1)$ & $(0.44,0.63,0.70,0.89,1)$ & $(0.44,0.67,0.67,1.00,1)$ \\
$C_{4}$ & $(0.13,0.42,0.46,0.75,1)$ & $(0.23,0.58,0.67,1.00,1)$ & $(0.25,0.46,0.54,0.75,1)$ \\
$C_{5}$ & $(0.44,0.63,0.70,0.89,1)$ & $(0.22,0.63,0.70,1.00,1)$ & $(0.56,0.67,0.78,0.89,1)$ \\
$C_{6}$ & $(0.00,0.21,0.29,0.63,1)$ & $(0.25,0.58,0.67,1.00,1)$ & $(0.13,0.42,0.46,0.75,1)$ \\
$C_{7}$ & $(0.20,0.37,0.43,0.60,1)$ & $(0.70,0.87,0.93,1.00,1)$ & $(0.50,0.73,0.77,0.90,1)$ \\
$C_{8}$ & $(0.22,0.44,0.56,0.89,1)$ & $(0.22,0.63,0.70,1.00,1)$ & $(0.44,0.70,0.74,1.00,1)$ \\
$C_{9}$ & $(0.20,0.37,0.43,0.60,1)$ & $(0.70,0.83,0.87,1.00,1)$ & $(0.50,0.67,0.73,0.90,1)$ \\
$C_{10}$ & $(0.13,0.42,0.46,0.75,1)$ & $(0.50,0.71,0.79,1.00,1)$ & $(0.13,0.33,0.42,0.63,1)$ \\
\hline
\end{tabular}

Table 9. Weighted normalized fuzzy decision matrix.

\begin{tabular}{cccc}
\hline Criteria & $A_{1}$ & $A_{2}$ & $A_{3}$ \\
\hline$C_{1}$ & $(0.18,0.31,0.37,1.00,1)$ & $(014,0.20,0.23,0.40,1)$ & $(0.16,0.22,0.24,0.40,1)$ \\
$C_{2}$ & $(0.09,0.33,0.40,0.80,1)$ & $(0.18,0.42,0.44,0.90,1)$ & $(0.09,0.28,0.37,0.80,1)$ \\
$C_{3}$ & $(0.16,0.48,0.62,0.89,1)$ & $(0.31,0.55,0.66,0.89,1)$ & $(0.31,0.58,0.62,1.00,1)$ \\
$C_{4}$ & $(0.05,0.22,0.26,0.60,1)$ & $(0.10,0.31,0.38,0.80,1)$ & $(0.10,0.24,0.31,0.60,1)$ \\
$C_{5}$ & $(0.22,0.46,0.54,0.80,1)$ & $(0.11,0.46,0.54,0.90,1)$ & $(0.28,0.49,0.60,0.80,1)$ \\
$C_{6}$ & $(0.00,0.12,0.18,0.50,1)$ & $(0.10,0.33,0.42,0.80,1)$ & $(0.05,0.24,0.29,0.60,1)$ \\
$C_{7}$ & $(0.08,0.21,0.27,0.48,1)$ & $(0.28,0.49,0.59,0.80,1)$ & $(0.20,0.42,0.49,0.72,1)$ \\
$C_{8}$ & $(0.11,0.33,0.43,0.80,1)$ & $(0.11,0.46,0.54,0.90,1)$ & $(0.22,0.52,0.57,0.90,1)$ \\
$C_{9}$ & $(0.04,0.13,0.19,0.36,1)$ & $(0.14,0.31,0.38,0.60,1)$ & $(0.10,0.24,0.32,0.54,1)$ \\
$C_{10}$ & $(0.05,0.29,0.32,0.68,1)$ & $(0.20,0.50,0.55,0.90,1)$ & $(0.05,0.23,0.29,0.56,1)$ \\
\hline
\end{tabular}

Table 10. Score of candidates (First similarity measure).

\begin{tabular}{cccc}
\hline & $\mathcal{S}_{1}{ }^{+}$ & $\mathcal{S}_{1}{ }^{*}$ & $\mathrm{CCS}_{1}$ \\
\hline$A_{1}$ & 0.6622 & 0.7944 & 0.4546 \\
$A_{2}$ & 0.7155 & 0.7358 & 0.4930 \\
$A_{3}$ & 0.6872 & 0.7687 & 0.4720 \\
\hline
\end{tabular}

Table 11. Score of candidates (Second similarity measure).

\begin{tabular}{cccc}
\hline & $S_{2}^{+}$ & $S_{2}^{*}$ & CCS $_{2}$ \\
\hline$A_{1}$ & 0.0467 & 0.1427 & 0.2465 \\
$A_{2}$ & 0.0796 & 0.1049 & 0.4315 \\
$A_{3}$ & 0.0641 & 0.1253 & 0.3385 \\
\hline
\end{tabular}


Table 12. Score of candidates (Third similarity measure).

\begin{tabular}{lccc}
\hline & $\mathcal{S}^{+}$ & $\mathcal{S}_{3}{ }^{+}$ & $\mathrm{CCS}_{3}$ \\
\hline$A_{1}$ & 0.4010 & 0.5849 & 0.4067 \\
$A_{2}$ & 0.4735 & 0.5016 & 0.4855 \\
$A_{3}$ & 0.4409 & 0.5633 & 0.4391 \\
\hline
\end{tabular}

Table 13. Score of candidates (Fourth similarity measure).

\begin{tabular}{cccc}
\hline & $S_{4}{ }^{+}$ & $S_{4}{ }^{*}$ & $\mathrm{CCS}_{4}$ \\
\hline$A_{1}$ & 0.2772 & 0.4072 & 0.4050 \\
$A_{2}$ & 0.3187 & 0.3467 & 0.4789 \\
$A_{3}$ & 0.3100 & 0.4049 & 0.4336 \\
\hline
\end{tabular}

Table 14. Average score of candidates.

\begin{tabular}{ccccccc}
\hline & $\mathrm{CCS}_{1}$ & $\mathrm{CCS}_{2}$ & $\mathrm{CCS}_{3}$ & $\mathrm{CCS}_{4}$ & Average & Rank \\
\hline$A_{1}$ & 0.4546 & 0.2465 & 0.4067 & 0.4050 & 0.3782 & 3 \\
$A_{2}$ & 0.4930 & 0.4315 & 0.4855 & 0.4789 & 0.4722 & 1 \\
$A_{3}$ & 0.4720 & 0.3385 & 0.4391 & 0.4336 & 0.4208 & 2 \\
\hline
\end{tabular}

cision-making tool. Limited documented data about candidate's performance have led decision makers to quantify fuzzy expressions. Fuzzy TOPSIS method translates these linguistic terms to be a basis of rational judgments. Extended TOPSIS makes final evaluation using similarity instead of closeness criteria, and utilizes fuzzy similarity instead of calculating the distance.

\section{References}

[1] Wei, S.H. and Chen, S.M. (2009) A New Approach for Fuzzy Risk Analysis Based on Similarity Measures of Generalized Fuzzy Numbers. Expert Systems with Applications, 36, 589-598. https://doi.org/10.1016/j.eswa.2007.09.033

[2] Hsieh, C.H. and Chen, S.H. (1999) Similarity of Generalized Fuzzy Numbers with Graded Mean Integration Representation. Proceedings of the 8th International Fuzzy Systems Association World Congress, Taipei, 551-555.

[3] Chen, C.-T., Lin, C.-T. and Huang, S.-F. (2006) A Fuzzy Approach for Supplier Evaluation and Selection in Supply Chain Management. International Journal of Production Economics, 102, 289-301. https://doi.org/10.1016/j.ijpe.2005.03.009

[4] Bhutta, K.S. and Huq, F. (2002) Supplier Selection Problem: A Comparison of the Total Cost of Ownership and Analytic Hierarchy Process Approaches. Supply Chain Management: An International Journal, 7, 126-135. https://doi.org/10.1108/13598540210436586

[5] Moore, S.B. and Manring, S.L. (2009) Strategy Development in Small and Medium Sized Enterprises for Sustainability and Increased Value Creation. Journal of Cleaner Production, 17, 276-282. https://doi.org/10.1016/j.jclepro.2008.06.004

[6] Giunipero, L.C., Denslow, D. and Eltantawy, R. (2005) Purchasing/Supply Chain Management Flexibility: Moving to an Entrepreneurial Skill Set. Industrial Marketing Management, 34, 602-613. https://doi.org/10.1016/j.indmarman.2004.11.004 
[7] Forlani, D. and Mullins, J.W. (2000) Perceived Risks and Choices in Entrepreneurs' New Venture Decisions. Journal of Business Venturing, 15, 305-322. https://doi.org/10.1016/S0883-9026(98)00017-2

[8] Dickson, P.R. (1996) The Static and Dynamic Mechanics of Competition: A Comment on Hunt and Morgan's Comparative Advantage Theory. The Journal of Marketing, 102-106. https://doi.org/10.2307/1251904

[9] Walker, G. and Weber, D. (1987) Supplier Competition, Uncertainty, and Make-orBuy Decisions. Academy of Management Journal, 30, 589-596. https://doi.org/10.2307/256017

[10] Hsu, C.-W. and Hu, A.H. (2009) Applying Hazardous Substance Management to Supplier Selection Using Analytic Network Process. Journal of Cleaner Production, 17, 255-264. https://doi.org/10.1016/j.jclepro.2008.05.004

[11] Çelebi, D. and Bayraktar, D. (2008) An Integrated Neural Network and Data Envelopment Analysis for Supplier Evaluation under Incomplete Information. Expert Systems with Applications, 35, 1698-1710.

[12] Noci, G. (1997) Designing Green Vendor Rating Systems for the Assessment of a Supplier's Environmental Performance. European Journal of Purchasing \& Supply Management, 3, 103-114.

[13] Sarkis, J. and Talluri, S. (2002) A Model for Strategic Supplier Selection. Journal of Supply Chain Management, 38, 18-28.

https://doi.org/10.1111/j.1745-493X.2002.tb00117.x

[14] Ragatz, G.L., Handfield, R.B. and Scannell, T.V. (1997) Success Factors for Integrating Suppliers into New Product Development. Journal of Product Innovation Management, 14, 190-202.

[15] Azzone, G. and Noci, G. (1998) Identifying Effective PMSs for the Deployment of “Green” Manufacturing Strategies. International Journal of Operations \& Production Management, 18, 308-335. https://doi.org/10.1108/01443579810199711

[16] Humphreys, P.K., Wong, Y.K. and Chan, F.T.S. (2003) Integrating Environmental Criteria into the Supplier Selection Process. Journal of Materials Processing Technology, 138, 349-356.

[17] Bai, C. and Sarkis, J. (2010) Green Supplier Development: Analytical Evaluation Using Rough Set Theory. Journal of Cleaner Production, 18, 1200-1210.

[18] Tseng, M.-L., Chiang, J.H. and Lan, L.W. (2009) Selection of Optimal Supplier in Supply Chain Management Strategy with Analytic Network Process and Choquet Integral. Computers \& Industrial Engineering, 57, 330-340.

[19] Awasthi, A., Chauhan, S.S. and Goyal, S.K. (2010) A Fuzzy Multicriteria Approach for Evaluating Environmental Performance of Suppliers. International Journal of Production Economics, 126, 370-378.

[20] Yeh, W.-C. and Chuang, M.-C. (2011) Using Multi-Objective Genetic Algorithm for Partner Selection in Green Supply Chain Problems. Expert Systems with Applications, 38, 4244-4253.

[21] Büyüközkan, G. and Çifçi, G. (2011) A Novel Fuzzy Multi-Criteria Decision Framework for Sustainable Supplier Selection with Incomplete Information. Computers in Industry, 62, 164-174.

[22] Zhu, Q. and Geng, Y. (2001) Integrating Environmental Issues into Supplier Selection and Management. Greener Management International, 2001, 26-40. https://doi.org/10.9774/GLEAF.3062.2001.au.00005

[23] Shaw, K., et al. (2012) Supplier Selection Using Fuzzy AHP and Fuzzy Multi-Objective Linear Programming for Developing Low Carbon Supply Chain. Expert Sys- 
tems with Applications, 39, 8182-8192.

[24] Govindan, K., Kannan, D. and Haq, A.N. (2010) Analyzing Supplier Development Criteria for an Automobile Industry. Industrial Management \& Data Systems, 110, 43-62. https://doi.org/10.1108/02635571011008399

[25] Safranek, T., et al. (2009) Outbreak of Salmonella Serotype Saintpaul Infections Associated with Eating Alfalfa Sprouts-United States, 2009. Morbidity and Mortality Weekly Report, 58, 500-503.

[26] Goodman, J.P., Meany, J.W. and Pate, L.E. (1992) The Government as Entrepreneur: Industrial Development and the Creation of New Ventures. The State of the Art on Entrepreneurship.

[27] Kickul, J. and Gundry, L. (2002) Prospecting for Strategic Advantage: The Proactive Entrepreneurial Personality and Small Firm Innovation. Journal of Small Business Management, 40, 85-97.

[28] Loasby, B.J. (1984) Entrepreneurs and Organisation. Journal of Economic Studies, 11, 75-88. https://doi.org/10.1108/eb002578

[29] Zhu, Q. and Sarkis, J. (2004) Relationships between Operational Practices and Performance among Early Adopters of Green Supply Chain Management Practices in Chinese Manufacturing Enterprises. Journal of Operations Management, 22, 265289.

[30] Lee, E.-K., Ha, S. and Kim, S.-K. (2001) Supplier Selection and Management System Considering Relationships in Supply Chain Management. IEEE Transactions on Engineering Management, 48, 307-318. https://doi.org/10.1109/17.946529

[31] Lu, L.Y.Y., Wu, C.H. and Kuo, T.-C. (2007) Environmental Principles Applicable to Green Supplier Evaluation by Using Multi-Objective Decision Analysis. International Journal of Production Research, 45, 4317-4331.

[32] Saaty, T.L. (1999) Decision Making for Leaders: The Analytic Hierarchy Process for Decisions in a Complex World. Vol. 2, RWS Publications.

[33] Schuwirth, L.W.T., et al. (2002) When Enough Is Enough: A Conceptual Basis for Fair and Defensible Practice Performance Assessment. Medical Education, 36, 925930. https://doi.org/10.1046/j.1365-2923.2002.01313.x

[34] Peeva, M. (2013) Stakeholder Selection in Cleantech Start-Ups and Stakeholder Contribution to New Venture's Outcome. Master's Thesis, University of Twente, Enschede, Netherlands.

[35] Zadeh, L.A. and Kacprzyk, J., Eds. (1999) Computing with Words in Information. In: Intelligent Systems 1: Foundations, Vol. 33, Springer, Berlin.

[36] Sargolzaei, A., Faez, K. and Sargolzaei, S. (2011) A New Method for Foetal Electrocardiogram Extraction Using Adaptive Nero-Fuzzy Interference System Trained with PSO Algorithm. 2011 IEEE International Conference on Electro/Information Technology(EIT), Mankato, MN, 15-17 May 2011, 1-5.

[37] Sargolzaei, A., Yen, K.K., Zeng, K., Motahari, S.M.A. and Noei, S. (2014) Impulse Image Noise Reduction Using Fuzzy-Cellular Automata Method. International Journal of Computer and Electrical Engineering, 6, 191-195. https://doi.org/10.7763/IJCEE.2014.V6.820

[38] Noei, S., Sargolzaei, S., Ramezanpour, H. and Sargolzaei, A. (2012) Fuzzy-Cellular Automata Method for Noise Cancelation of Satellite and Radar Images and Maps. International Journal of Emerging Technology and Advanced Engineering, 22502459.

[39] Widom, J. (2004) Trio: A System for Integrated Management of Data, Accuracy, and Lineage. Technical Report. 
[40] Yoon, K.P. and Hwang, C.-L. (1995) Multiple Attribute Decision Making: An Introduction. Vol. 104, Sage Publications, Thousand Oaks, CA. https://doi.org/10.4135/9781412985161

[41] Sun, C.-C. (2010) A Performance Evaluation Model by Integrating Fuzzy AHP and Fuzzy TOPSIS Methods. Expert Systems with Applications, 37, 7745-7754.

[42] Collan, M. and Luukka, P. (2014) Evaluating R\&D Projects as Investments by Using an Overall Ranking from Four New Fuzzy Similarity Measure Based TOPSIS Variants. IEEE Transactions on Fuzzy Systems, 22, 505-515.

https://doi.org/10.1109/TFUZZ.2013.2260758

[43] Shen, L., Olfat, L., Govindan, K., Khodaverdi, R. and Diabat, A. (2013) A Fuzzy Multi Criteria Approach for Evaluating Green Supplier's Performance in Green Supply Chain with Linguistic Preferences. Resource Conservation and Recycling, 74, 170-179.

Submit or recommend next manuscript to SCIRP and we will provide best service for you:

Accepting pre-submission inquiries through Email, Facebook, LinkedIn, Twitter, etc. A wide selection of journals (inclusive of 9 subjects, more than 200 journals)

Providing 24-hour high-quality service

User-friendly online submission system

Fair and swift peer-review system

Efficient typesetting and proofreading procedure

Display of the result of downloads and visits, as well as the number of cited articles Maximum dissemination of your research work

Submit your manuscript at: http://papersubmission.scirp.org/

Or contact ajibm@scirp.org 